\title{
24. GEOCHEMISTRY, DIAGENESIS, AND PETROLOGY OF AN UPPER CRETACEOUS RUDIST REEF FROM SITE 877, WODEJEBATO GUYOT ${ }^{1}$
}

\author{
Bradley N. Opdyke, ${ }^{2}$ Paul A. Wilson, ${ }^{3}$ and Paul Enos ${ }^{4}$
}

\begin{abstract}
An Upper Cretaceous, tightly cemented rudist "reef" was cored at Site 877, Wodejebato Guyot, during Leg 144. Recovered samples include metastable carbonates such as $7 \mathrm{~mol} \% \mathrm{Mg}$-calcite marine cements and preserved aragonite rudist shell material. Trace- and minor-element data as well as stable isotopic data indicate that alteration to neomorphic marine calcite occurred in colder, presumably deeper waters. There is little evidence, petrographic or chemical, of pervasive alteration by meteoric water.

Water temperatures calculated from the $\delta^{18} \mathrm{O}$ composition of aragonitic rudist fragments as well as the most magnesian calcite marine cements are approximately $27^{\circ} \mathrm{C}$ and are similar to modern tropical sea-surface water temperatures. Strontium contents of the most magnesium-rich marine cements are at least double those of similar magnesium content today, implying that the strontium concentration of Late Cretaceous seawater was at least twice that of Quaternary seawater. These data support the hypothesis that shallow-water carbonate sedimentation was dominated by calcite rather than aragonite burial at the end of the Mesozoic.
\end{abstract}

\section{INTRODUCTION}

When available, appropriately well-preserved carbonate marine cements provided good records of record paleocean $\delta^{18} \mathrm{O}$ and $\delta^{13} \mathrm{C}$ (e.g., Lohmann, 1988). Similarly, analysis of marine biotic calcite and aragonite is a well-established paleoceanographic practice when analyzing $\delta^{18} \mathrm{O}$ and $\delta^{13} \mathrm{C}$ (e.g., Emiliani, 1955; Popp et al., 1986). However, using biotic precipitates as tracers for minor elements in the paleoceans is more problematic because of the preponderance of vital effects that deviate the concentrations of minor elements in these precipitates from equilibrium values (e.g., Elderfield et al., 1992). Well-preserved marine cements are ideal for extracting data concerning possible changes in the minor-element chemistry of the ocean (Given and Lohmann, 1985; Lohmann, 1988; Carpenter et al., 1991). Unfortunately, metastable aragonite and magnesian calcite marine cements, especially those precipitated at shallow water depths, are rarely preserved in the rock record (e.g., Brand and Veizer, 1980).

One of the primary goals of this study was to determine if any limestone recovered from Hole 877A would be useful in determining paleotemperatures and chemical composition of Late Cretaceous surface water. An unusually well-cemented rudist reef was recovered at Hole 877A. In one interval (144-877A-5R-3, 30-50 and 66-109 cm; rudist rudstone; Premoli Silva, Haggerty, Rack, et al., 1993), cementation was dense enough to protect enclosed metastable carbonates from subsequent contact with diagenetic fluids. Hole $877 \mathrm{~A}$ is relatively unusual because the data presented in this paper demand that the diagenetic fluids reacting with the metastable carbonates have been almost entirely of marine origin, a very different paragenesis from most terrestrial analogs in which early diagenesis is meteoric in origin. Lack of evidence for substantial meteoric stabilization also is unusual when compared to studies of diagenesis of living atolls (Saller and Moore, 1989; Quinn, 1991; Aharon, 1993). The absence of significant meteoric diagenetic alteration in Hole 877A shallow-

\footnotetext{
${ }^{1}$ Haggerty, J.A., Premoli Silva, I., Rack, F., and McNutt, M.K. (Eds.), 1995. Proc. ODP, Sci. Results, 144: College Station, TX (Ocean Drilling Program).

${ }^{2}$ Department of Geological Sciences, University of Michigan, Ann Arbor, MI 48109. U.S.A. (Present address: Department of Geology, Faculty of Science, The Australian National University, Canberra ACT 0200, Australia.)

${ }^{3}$ Department of Earth Sciences, University of Cambridge, Downing Street, Cambridge CB2 3EQ, United Kingdom.

${ }^{4}$ Department of Geology, University of Kansas, 120 Lindley Hall, Lawrence, KS 66045 , U.S.A.
}

water carbonates implies an absence of sea-level falls for the duration of deposition of these limestones. Such a scenario is consistent with the hypothesized "ice free" world at the time (Savin, 1977). In the following study, we describe the petrographic and geochemical diagenetic evolution of limestones of Hole 877A. Biotic allochems as well as marine cements offer valuable information concerning the temperature and chemistry of the seawater in the Late Cretaceous.

\section{METHODS}

Marine cements and various allochems were drilled to powder using a 0.5 -mm drill bit under a binocular microscope stage. Samples were relatively large, up to $10 \mathrm{mg}$. We split $1-2 \mathrm{mg}$ from this powder for $\delta^{13} \mathrm{C}, \delta^{18} \mathrm{O}, \mathrm{F}, \mathrm{Mg}, \mathrm{Ca}, \mathrm{Sr}, \mathrm{Mn}$, and $\mathrm{Fe}$ analyses at the University of Michigan. The remaining powder was analyzed for ${ }^{87} \mathrm{Sr} /{ }^{86} \mathrm{Sr}$ at Cambridge University (Wilson et al., this volume).

Direct analysis of $\mathrm{Ca}, \mathrm{Mg}, \mathrm{Sr}, \mathrm{Fe}$, and $\mathrm{Mn}$ was possible in the same solution by simultaneous inductively coupled plasma atomic emission spectroscopy (ICP-AES) using a Leeman Labs Plasma-Spec III $( \pm 1 \%$ precision). A split of the same sample powder was analyzed for $\delta^{13} \mathrm{C}$ and $\delta^{18} \mathrm{O}$ by mass spectrometry. Each $1-\mathrm{mg}$ sample was dissolved in $1.25 \mathrm{~cm}^{3}$ of double-distilled $\mathrm{H}_{2} \mathrm{O}$ with $50 \mu \mathrm{l}$ of $5 \% \mathrm{HCl}$. Fluoride was analyzed on an aliquot of solution using a Dionex $4000 \mathrm{i}$ series ion chromatograph (IC) by conductivity detection $( \pm 1.5 \%$ precision based on repetitive analysis of matrix-matched standards). The hydrophobic AS2 column was used with dilute $\mathrm{NaOH}$ for isocratic analysis, followed by stepwise cleanup to remove other anions. No interferences with the F peak were found. Separation with the chloride peak is over a minute. Precision of replicate analyses of a standard powder run on different days was typically $\pm 60 \mathrm{ppm}$ F. Stable isotopic analyses were preformed on a Finnigan MAT 251 with a Kiel device, which allows individual reaction for each sample and provides $\delta^{18} \mathrm{O}$ values to $\pm 0.04 \%$ o PDB (relative to the Peedee belemnite) and $\delta^{13} \mathrm{C}$ to $\pm 0.01 \%$ PDB.

\section{RESULTS \\ Petrology}

Marine cements are abundant at Hole 877A and occur throughout the core. Cements fill both primary and secondary porosity (Choquette and Pray, 1970) and show a course correlation to the drilling speed, under the assumption that the more densely cemented a limestone is, the more time it takes for the drill to penetrate the rock (Fig. 1). 


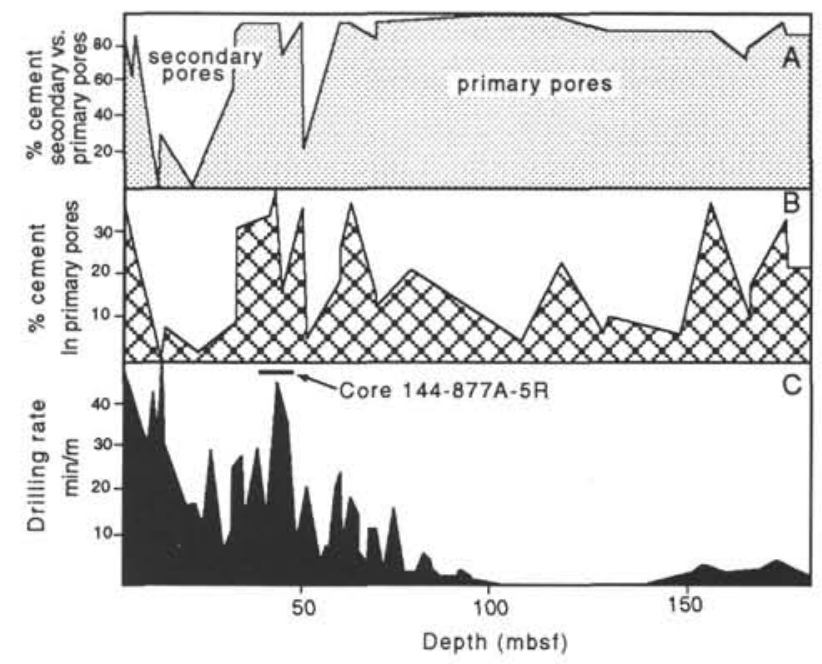

Figure 1.A. Relative abundance of primary and secondary pore-filling cements downcore. B. Absolute abundance of cement in primary pores with depth. C. Drilling rate, in minutes per meter, at Hole $877 \mathrm{~A}$. Note the slow drilling rate through Core 144-877A-5R.

Cements filling secondary porosity are important within the first 35 $\mathrm{m}$ of the core. Throughout the rest of the core, cements fill largely primary pore spaces (Fig. 1). Cement in primary pores varies from $0 \%$ to $40 \%$ throughout the core, the most important cemented interval being the early marine cements in Core 144-877A-5R.

One of the exciting aspects of Hole $877 \mathrm{~A}$ is the presence of abundant early marine cements, particularly in Cores 144-877A-1R through -7R (Plate 1). Marine cements have been separated into three different types petrographically: radiaxial cement (RC); radiaxial fibrous cement (RC-FIC); and columnar cement (CC). Late cements have been classified as pyramidal-limpid-uniform extinction cement (PLUC) and syntaxial overgrowth cement (O/S) (Table 1). Within the upper part of the hole, Core 144-877A-5R is the most densely cemented and has provided the most metastable carbonate for geochemical analysis. This important cement is found in Section 144877A-5R-3 and is largely the CC (Table 1 and Plate 1). Description of the marine cements can be further delineated between the types of cements, where they were specifically obtained in the core, and whether they were precipitated in primary or secondary pore space (Fig. 2). Geochemical analyses were not conducted to the detail of the above petrography because of the relatively large quantity of carbonate powder needed to run all the measurements. Such analyses will proceed in the future.

\section{Geochemistry}

\section{Stable Isotopes}

Marine cements as well as various allochems, such as rudist clasts, and a coral fragment were sampled for stable isotopic analysis. Rudists are composed of both Caprinid and Radiolitid genera (Camoin et al., this volume). Typically, the aragonite in these allochems is altered to calcite. However, within Section 144-877A-5R-3 rudist valves that are still $100 \%$ aragonite are quite common. The $\delta^{18} \mathrm{O}$ of the aragonite is typically between $-2.0 \%$ and $-2.9 \%$ PDB. The most magnesium-rich marine cements also have $\delta^{18} \mathrm{O}$ values that cluster between $-2.6 \%$ and $-2.0 \%$ PDB. Measurements of RC cement largely overlap the stable isotope values of the altered allochems $\left(\delta^{18} \mathrm{O}\right.$ values from $-3.0 \%$ to $0 \%$ PDB). The PLUC cement has a positive $\delta^{18} \mathrm{O}$ value of $1.1 \%$ PDB, implying cold water, consistent with the interpretation of it being a late marine precipitate. Calcitic portions of the rudist shells contained the lowest $\delta^{18} \mathrm{O}$ values $\left(-5.0 \%\right.$ to $-3.0 \%$ PDB) and a $\delta^{13} \mathrm{C}$ value of ap- proximately $1.5 \%$ PDB. One coral sample yielded values of $-3.0 \%$ and $4.5 \%$ for $\delta^{18} \mathrm{O}$ and $\delta^{13} \mathrm{C}$, respectively (Fig. 3 and Table 2).

\section{Minor Elements}

Measuring fluoride provided a valuable diagenetic constraint on different biogenic allochems as well as on the marine cements. Rudists, like modern mollusks, are very efficient at determining the minorelement chemistry of the shell material they precipitate. Fluoride anions are largely excluded from most mollusk shell material (Carpenter, 1969). In contrast, foraminifers, marine cements, and corals all incorporate large amounts of $\mathrm{F}$ in their calcite and aragonite lattices. Inorganic marine calcite cements, like planktonic foraminifers, appear to incorporate more $\mathrm{F}$ into the calcite lattice at higher temperatures/precipitation rates (Opdyke et al., 1993). Most of the rudist material, with the exception of the presently calcitic portion of the shell, have uniformly low F contents, no matter what the relative state of alteration, whether determined by textural, stable isotope, or minor-element changes. Marine cements, as well as other calcite (and aragonite) that originally incorporate significant $\mathrm{F}(300-900 \mathrm{ppm} F)$, progressively lose $\mathrm{F}$ as the calcites undergo progressive neomorphism in colder, less saturated water. The PLUC cements that are presumably precipitated in deeper, colder water begin with a low F content (113 ppm). One complicating factor is the presence of a late (yellow) phosphate-rich cement in the upper portion of the core (Premoli Silva, Haggerty, Rack, et al., 1993). This phosphatic cement causes the high $\mathrm{F}$ contents recorded at a $\delta^{18} \mathrm{O}$ of $-1.0 \%$ PDB (Fig. 4 and Table 2).

The high magnesium content of the marine cements and the low magnesium content of the rudists clearly show the two most metastable (i.e., the best preserved end members). The $7 \mathrm{~mol} \%$ calcite cements, largely $\mathrm{CC}$, also have the lowest $\delta^{18} \mathrm{O}$ of the marine cements. As stated above, marine neomorphism of these cements results in higher $\delta^{18} \mathrm{O}$ values as opposed to alteration by meteoric water, which tends to lower $\delta^{18} \mathrm{O}$ values. Late PLUC cements contain only $2 \mathrm{~mol} \%$ $\mathrm{Mg}$. The aragonite rudist fragments contain very little $\mathrm{Mg}$, and $\mathrm{Mg}$ is only added as the shell fragments undergo marine diagenesis (Fig. 5)

Strontium concentrations are, for the most part, very low throughout the hole, with the exception of the magnesium-rich calcites, the aragonite-rich coral fragment, and the aragonitic portions of the rudists found in Core $144-877 \mathrm{~A}-5 \mathrm{R}$. The coral fragment has a $\mathrm{Sr}$ content of $8000 \mathrm{ppm}$ in spite of the fact that $25 \%$ of the sample measured is probably calcite cement (based on its $\mathrm{Mg}$ content and petrography). Aragonitic rudist fragments have $\mathrm{Sr}$ concentrations in the range of modern mollusk shell material, between 2000 and 3000 ppm (Milliman, 1974). However, the Sr content of the CC is at least double the $\mathrm{Sr}$ content of modern $\mathrm{Mg}$-calcites of the same origin $(\mathrm{Sr}=$ 690-1500 ppm) (Fig. 6). The two most metastable components studied (coral fragment not included), the aragonite rudists and the $\mathrm{Mg}$ calcites, are clearly defined when $\mathrm{Sr}$ is plotted vs. $\mathrm{Mg}$ (Fig. 7). These metastable components have been dated as Maastrichtian in age using strontium isotope stratigraphy (Wilson et al., this volume). The geochemical signature of the thermodynamically stable marine neomorphic end member is clearly defined at approximately $2 \mathrm{~mol} \% \mathrm{Mg}$.

\section{DISCUSSION AND CONCLUSIONS}

In Section 144-877A-5R-3, we recovered metastable material that has allowed a rare look at the marine geochemistry of the Maastrichtian. Well-preserved aragonitic rudist shells yield valuable data with respect to the diagenetic history of the Wodejebato carbonate platform and the stable isotopic value of Late Cretaceous surface seawater. However, the rudists do not contribute the same unambiguous data from their $\mathrm{Mg}, \mathrm{Sr}$, and $\mathrm{F}$ content because mollusks, like mollusks today, have low minor cation and anion concentrations in comparison to carbonates that precipitate in equilibrium with seawater. Fortunately, inorganically precipitated $\mathrm{Mg}$-calcite marine cements largely reflect the chemistry of the water from which they precipitate, both with 
CEMENTS SITE 877

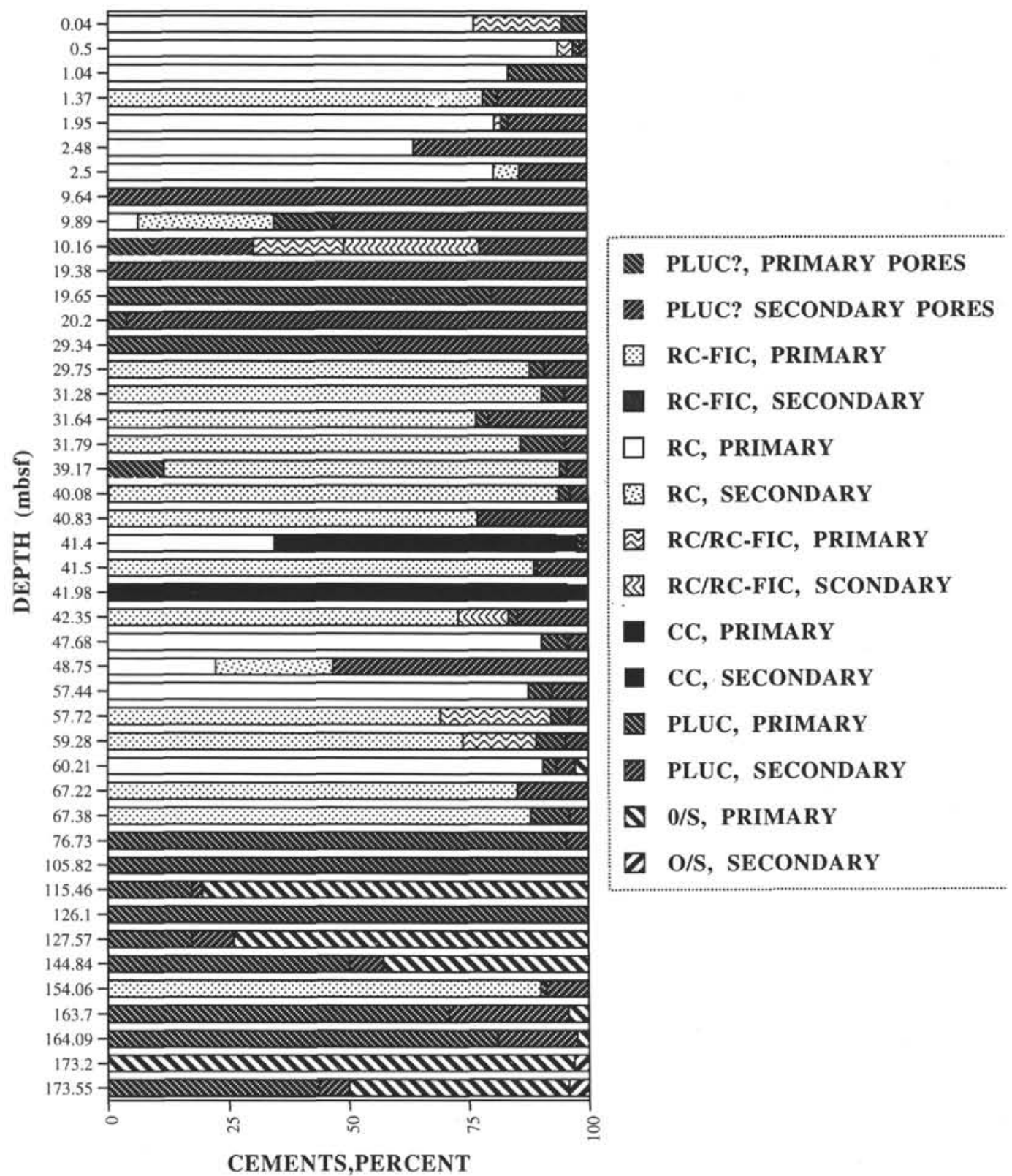

Figure 2. A division of cement types, with depth, where point counting was done.

respect to the minor elements as well as the stable isotopic values (Lohmann, 1988). The densely cemented limestone in Section 144$877 \mathrm{~A}-5 \mathrm{R}-3$ has preserved the early geochemical signature of both the bioclasts and the inorganically precipitated material.

The $7 \mathrm{~mol} \% \mathrm{Mg}$-calcites and the portions of the rudists that are still aragonite should give relatively reliable calculated paleotemperatures, based on their $\delta^{18} \mathrm{O}$ values. The paleotemperature can then be calculated using the equation $T=a+b(\delta c+\delta w)+c(\delta c-\delta w)^{2}$ where $T$ is the temperature in $C, \delta c$ is the $\delta^{18} \mathrm{O}$ of the calcite, and $\delta w$ is the $\delta^{18} \mathrm{O}$ of the water. In this empirical equation, $a, b$, and $c$ were defined by Horibe and Oba (1972) for mollusks to be 17.04, -4.34 , and 0.16 , respectively. To calculate the paleotemperature at which these rudists grew, two assumptions about the $\delta^{18} \mathrm{O}$ of the Maastrichtian seawater are as follows: (1) the world is "ice free" at this time, which drops $\delta w$ from 0 to -1 ; and (2) in modern oceans, tropical to subtropical surface water $\delta^{18} \mathrm{O}$ typically is $0.5 \%$ > Standard Mean Ocean Water (SMOW) because of evaporation effects (Broecker, 1989). If we assume that the Late Cretaceous surface water in the southwestern Pacific Ocean had a similar evaporation/precipitation balance, then a best estimate for a water value for the Maastrichtian at Wodejebato Guyot is approximately $-0.5 \%$ for $\delta w$. Given the above assumptions, the warmest temperature calculated is $27^{\circ} \mathrm{C}$, for an aragonite $\delta^{18} \mathrm{O}$ of $-2.9 \%$ PDB. Using O'Neil et al.'s (1969) equation for inorganic precipitates, where $a=16.9, b=-4.68$, and $c=0.1$, the warmest temperature calculated for the cements measured is also $27^{\circ} \mathrm{C}$, for a calcite $\delta^{18} \mathrm{O}$ of $-2.6 \%$ PDB. Both of these calculated temperatures are within the normal range when compared to sea-surface temperatures at similar latitudes today. It is important to note that increasing the assumed salinity $(\delta w)$ would lower the calculated temperature.

Fluoride has proved useful as a diagenetic tracer. In the neritic carbonates from Hole $877 \mathrm{~A}$, fluoride separates formerly molluscan aragonitic components from those that were calcite in origin. As 
Table 1. Petrographic summary of cements in platform carbonates, Hole 877A.

\begin{tabular}{|c|c|c|}
\hline Type & Eswential characteristics & Other attributes \\
\hline $\mathrm{RC}$ & $\begin{array}{l}\text { Radiaxial cement. Inclusion-rich. Sweeping } \\
\text { extinction. convergent optic axes in subcrystals. }\end{array}$ & $\begin{array}{l}\text { Crystals generally elongate, but some are equant. Distributed as isopachous crusts. Crystal boundaries vague to } \\
\text { irregular with multiple subcrystals. Commonly grades into overlying cement. obscuring terminations. Acute } \\
\text { angle terminations common: multiple terminations rare. Occurs in primary pores with a few exceptions. Locally } \\
\text { reduces molds or vugs heneath a bored, corroded hard ground or exposed surface (Samples } 144-877 \mathrm{~A}-1 \mathrm{R}-2 \text {. } 100 \\
\mathrm{~cm} \text {. and }-6 \mathrm{R}-1.155 \mathrm{~cm} \text { ). Occurs in molds without apparent hiatus in Samples } 144-877 \mathrm{~A}-2 \mathrm{R}-1.39 \mathrm{~cm} \text {. and }-2 \mathrm{R} \text { - } \\
1.66 \mathrm{~cm} \text {. Invariably an early cement: first generation or overlying radiaxial fibrous cement, Occurs in top part of } \\
\text { cored interval (Cores } 144-877 \mathrm{~A}-1 \mathrm{R} \text { through }-7 \mathrm{R} \text { ). }\end{array}$ \\
\hline RC-FIC & $\begin{array}{l}\text { Radiaxial fibrous cement. Fibrous subcrystals with } \\
\text { bladed or equant aggregate habit, Inclusion rich. } \\
\text { commonly handed. Sweeping extinction. } \\
\text { convergent optic axes. Isopachous distribution. } \\
\text { Fibrous variant of RC. }\end{array}$ & $\begin{array}{l}\text { Crystal boundaries vague to irregular. Grades into overlying cement (RC. CC. or PLUC). Multiple acute } \\
\text { terminations rarely visible. Occurs exclusively in primary pores, except in Samples } 144-877 \mathrm{~A}-5 \mathrm{R}-2.60 \mathrm{~cm} \\
(<1 \%) \text {. and }-5 \mathrm{R}-3.135 \mathrm{~cm} \text { (beneath a disconformity). Invariably an early cement: first generation except in two } \\
\text { simples }(144-877 \mathrm{~A}-5 \mathrm{R}-1.117 \mathrm{~cm} \text {. and }-5 \mathrm{R}-2.60 \mathrm{~cm}) \text {. Occurs in Cores } 144-877 \mathrm{~A}-1 \mathrm{R} \text { through }-8 \mathrm{R} \text {. }\end{array}$ \\
\hline $\mathrm{CC}$ & $\begin{array}{l}\text { Columnar cement (elongate/bladed). Clear. } \\
\text { Sweeping extinction with convergent optic axes. } \\
\text { Generally pore filling with sutured. polygonal } \\
\text { houndaries. }\end{array}$ & $\begin{array}{l}\text { Occurs throughout Section } 144-877 \mathrm{~A}-5 \mathrm{R}-3 \text { and is very abundant ( } 16 \%-14 \% \text { bulk volume). Mostly lining primary } \\
\text { pores (intergranular and intragranular). but occurs in molds also. Irregular or curving crystal boundaries: acute or } \\
\text { gradational terminations. }\end{array}$ \\
\hline PLUC & $\begin{array}{l}\text { Pyramidal cement (generally bladed). Limpid (clear. } \\
\text { local inclusions in early growth stages). Uniform } \\
\text { extinction. }\end{array}$ & $\begin{array}{l}\text { Pore-lining crusts, but variable thickness: extreme size range. Folk classes } 2 \text { through } 6 \text {. Linear crystal boundaries: } \\
\text { acute terminations typical, but obtuse to rounded termini common in small crystals: uniform extinction (locally } \\
\text { slightly sweeping in early stages where syntaxial on RC). Occurs in all pore types. primary and secondary, and in } \\
\text { virtually all samples. Last phase of cement except where coprecipitated with or enveloped by syntaxial cement. } \\
\text { O/S near base of section (Cores } 144-877 \mathrm{~A}-10 \mathrm{R} \text { and - } 19 \mathrm{R} \text { ). }\end{array}$ \\
\hline $\mathrm{O} / \mathrm{S}$ & $\begin{array}{l}\text { Syntaxial overgrowth cement on echinoderms. } \\
\text { bivalves, and some large benthic foraminifers. }\end{array}$ & $\begin{array}{l}\text { Typically clear. patchy distribution (substrate control). linear. crystal boundaries, obtuse or multiple terminations. } \\
\text { uniform extinction. In primary pore space (BP and WP) with few exceptions. Late: abuts or envelopes PLUC. } \\
\text { Occurs only in lower part of interval (Cores 144-877A-IOR through-19R) where RC cement is lacking. }\end{array}$ \\
\hline
\end{tabular}

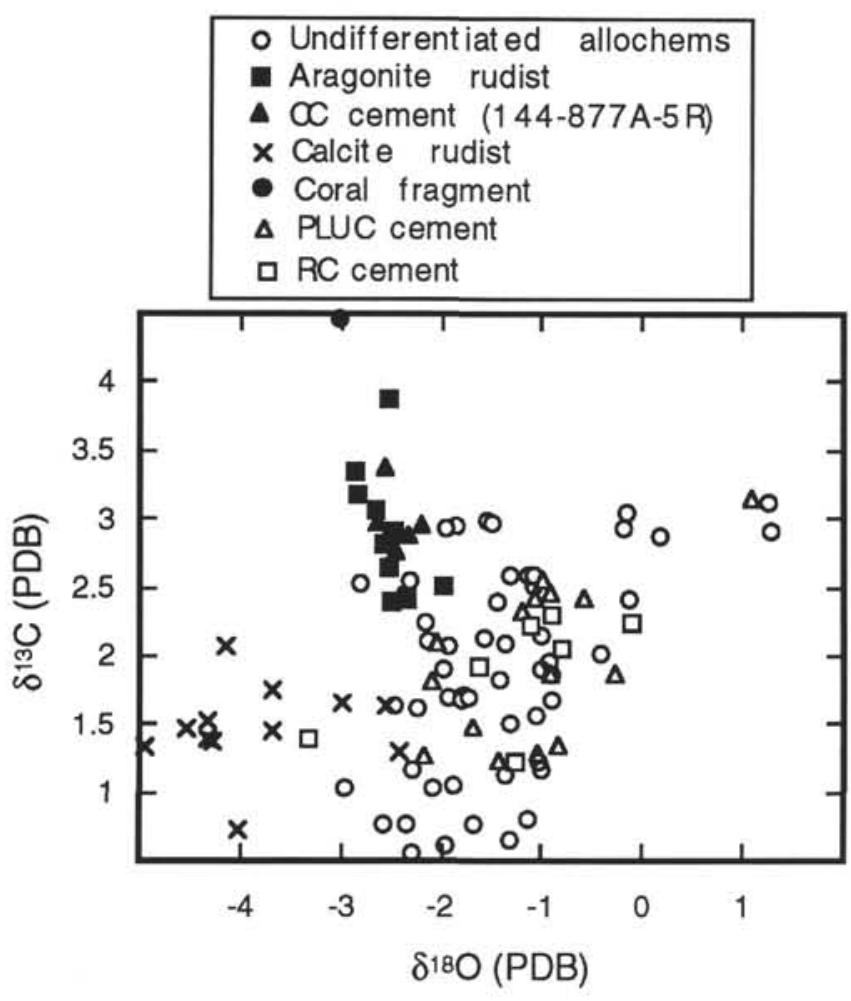

Figure 3. $\delta^{18} \mathrm{O}$ and $\delta^{13} \mathrm{C}$ of the samples measured. Differentiation of components was done petrographically. Note the isotopic overlap between the rudists and the columnar cements.

expected, those relatively pristine marine columnar cements that were precipitated in warmer water contain four to five times the fluoride than has been measured in later neomorphic calcite cements (Fig. 3). The high fluoride contents measured in the coral fragment also attest to the relatively pristine nature of this skeletal carbonate allochem.

Given the metastability of $7 \mathrm{~mol} \% \mathrm{Mg}$-calcite, its preservation in Hole $877 \mathrm{~A}$ is unusual. Two factors appear to have contributed to its

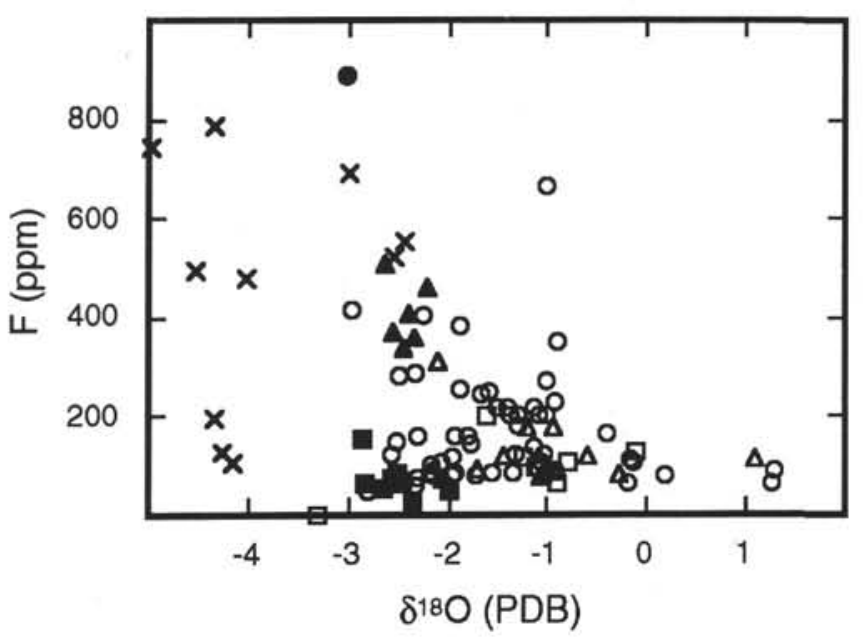

Figure 4. Fluoride vs. $\delta^{18} \mathrm{O}$, showing the differentiation between the aragonitic rudist fragments and the other cements and allochems. Diagenesis moves F to lower concentrations and $\delta^{18} \mathrm{O}$ to higher values. Symbols are the same as in Figure 3.

preservation at Site 877 . First, the density of the cementation prevented subsequent percolation of colder, lower saturation marine fluids. Second, unlike terrestrial exposures of limestone, little evidence exists that this site experienced pervasive contact with meteoric water, in terms of petrology and the stable isotopes, where the $\delta^{18} \mathrm{O}$ of the calcite tends to move to more negative values (e.g., Lohmann, 1988). However, one negative $\delta^{18} \mathrm{O}$ trend is associated exclusively with the calcite portion of the rudist shell, or perhaps in some cases with the calcitized portions of the former aragonite shell material. It is unlikely that this has been caused by meteoric alteration because the most negative $\delta^{18} \mathrm{O}$ values are associated with the highest concentrations of both $\mathrm{Sr}$ and $\mathrm{F}$ within that population.

The marine columnar cements in Core $144-877 \mathrm{~A}-5 \mathrm{R}$ provide a glimpse of the $\mathrm{Sr} / \mathrm{Mg}$ of Maastrictian seawater. Carpenter et al. (1991) argued on the basis of the higher ratio (of $\mathrm{Sr} / \mathrm{Ca}$ to $\mathrm{Mg} / \mathrm{Ca}$ in marine cements from the Devonian vs. those cements from Holocene marine 


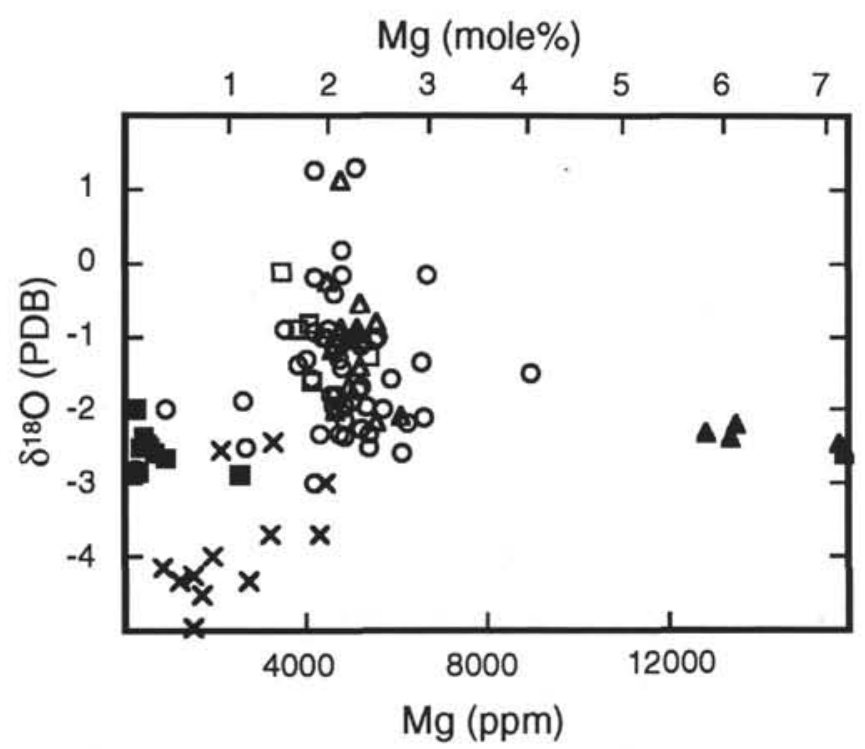

Figure $5 . \mathrm{Mg}$ vs. $\delta^{18} \mathrm{O}$. The $7 \mathrm{~mol} \% \mathrm{Mg}$-calcite is clearly contrasted with those samples that have reequilibrated with marine water at depth $(2 \mathrm{~mol} \% \mathrm{Mg}$-calcite). Symbols are the same as in Figure 3.

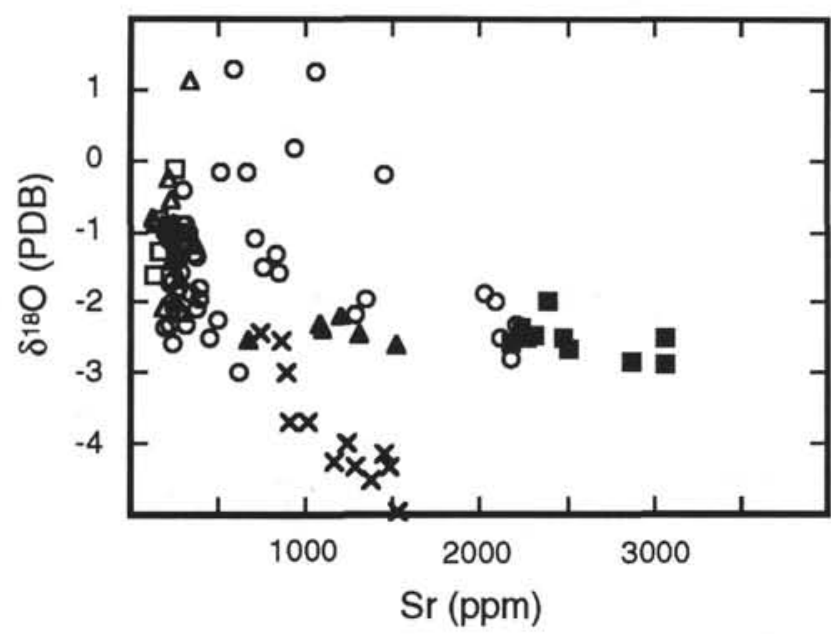

Figure 6. Sr vs. $\delta^{18} \mathrm{O}$ highlights the high $\mathrm{Sr}$ concentration in the coral sample as well as the calcite rudist trend, where more negative $\delta^{18} \mathrm{O}$ correlates to higher $\mathrm{Sr}$ contents. Symbols are the same as in Figure 3.

fluids) that the $\mathrm{Sr}$ content of Devonian seawater was higher than today. Given that modern marine cements with $7 \mathrm{~mol} \% \mathrm{Mg}$ contain only about $400 \mathrm{ppm} \mathrm{Sr}$ and that $\mathrm{Sr}$ concentrations range from 680 to 1500 for the Mg-calcite from Wodejebato Guyot, a much higher $\mathrm{Sr}$ concentration is probable for seawater from the Late Cretaceous. Higher Sr concentrations would be expected in a "calcite sea" where little (compared to today) aragonite is precipitated either organically or inorganically (Sandberg, 1983). The remarkable preservation of metastable aragonite and $\mathrm{Mg}$-calcite end members encountered in Hole 877 A serves to emphasize the difficulties geochemists usually encounter as they are typically faced with carbonate rocks that have been diagenetically homogenized to $2 \mathrm{~mol} \% \mathrm{Mg}$-calcite. Finally, the lack of clear horizons of diagenetic alteration within the limestone caused by meteoric water like those seen in modern atolls is itself strong evidence of the stability of sea level during the history of neritic sedimentation at Wodejebato Guyot.

\section{ACKNOWLEDGMENTS}

We would like to thank the staff of the Ocean Drilling Program and the crew of the JOIDES Resolution for their support, J.S. Compton and R. J. Behl for thoughtful reviews, and R. Barwick for his help with the graphics. We also thank L.M. Walter and K.C. Lohmann for access to their laboratories at the University of Michigan. This work was supported by a Research Studentship from The British Council BCMON/2234 (P.A.W.) and USSSP \#144-20751b (B.N.O.).

\section{REFERENCES*}

Aharon, P., 1993. Sea-level events in the South Pacific linked with the Messinian salinity crisis. Geology, 21:771-775.

Brand, U., and Veizer, J., 1980. Chemical diagenesis of a multicomponent carbonate system. I: Trace elements. J. Sediment. Petrol., 50:1219-1236.

Broecker, W.S., 1989. The salinity contrast between the Atlantic and Pacific Oceans during glacial time. Paleoceanography, 4:207-212.

Carpenter, R., 1969. Factors controlling the marine chemistry of fluorine. Geochem. Cosmochim. Acta, 33:1153-1167.

Carpenter, S.J., Lohmann, K.C., Holden, P., Walter, L.M., Huston, T.J., and Halliday, A.N., 1991. $8^{18} \mathrm{O}$ values, ${ }^{87} \mathrm{Sr} /{ }^{86} \mathrm{Sr}$ and $\mathrm{Sr} / \mathrm{Mg}$ ratios of Late Devonian abiotic marine calcite: implications for the composition of ancient seawater. Geochim. Cosmochim. Acta, 55:1991-2010

Choquette, P.W., and Pray, L.C., 1970. Geologic nomenclature and classification of porosity in sedimentary carbonates. AAPG Bull., 54:207-250.

Elderfield, H., Bertram, C.J., and Erez, J., 1992. Trace metals incorporationin foraminiferal calcite as a function of water column chemistry: model results and examples from $\mathrm{Sr} / \mathrm{Ca}$ and REE/Ca data. Progr. Abstr., ICP IV, Kiel, Germany, 104.

Emiliani, C., 1955. Pleistocene temperatures. J. Geol., 63:538-578.

Given, R.K., and Lohmann, K.C, 1985. Derivation of the original isotopic composition of Permian marine cements. J. Sediment. Petrol., 55:430-439.

Horibe, Y., and Oba, T., 1972. Temperature scales of aragonite-water and calcite-water systems. Fossils, 23/24:69-74.

Lohmann, K.C., 1988. Geochemical patterns of meteoric diagenetic systems and their application to studies of paleokarst. In James, N.P., and Choquette, P.W. (Eds.), Paleokarst: New York (Springer-Verlag), 58-80.

Milliman, J.D., 1974. Marine Carbonates (2nd ed.): Berlin (Springer-Verlag).

O'Neil, J.R., Clayton, R.N., and Mayeda, T.K., 1969. Oxygen isotope fractionation in divalent metal carbonates. J. Chem. Phys., 51:5547-5558.

Opdyke, B.N., Walter, L.M., and Huston, T.J., 1993. Fluoride content of foraminiferal calcite: relations to life habitat, oxygen isotope composition, and minor element chemistry. Geology, 21:169-173.

Popp, B.N., Anderson, T.F., and Sandberg, P.A., 1986. Brachiopods as indicators of original isotopic compositions in some Paleozoic limestones. Geol. Soc. Am. Bull., 97:1262-1269.

Premoli Silva, I., Haggerty, J., Rack, F., et al., 1993. Proc. ODP, Init. Repts., 144: College Station, TX (Ocean Drilling Program).

Quinn, T.M., 1991. Meteoric diagenesis of post-Miocene limestones on Enewetak Atoll. J. Sediment. Petrol., 61:681-703.

Saller, A.H., and Moore, C.H., Jr., 1989. Meteoric diagenesis, marine diagenesis, and microporosity in Pleistocene and Oligocene limestones, Enewetak Atoll, Marshall Islands. Sediment. Geol., 63:253-272.

Sandberg, P.A., 1983. An oscillating trend in Phanerozoic non-skeletal carbonate mineralogy. Nature, 305:19-22.

Savin, S.M., 1977. The history of the Earth's surface temperature during the past 100 million years. Annu. Rev. Earth. Planet Sci., 5:319-355.

\footnotetext{
- Abbreviations for names of organizations and publications in ODP reference lists follow the style given in Chemical Abstracts Service Source Index (published by American Chemical Society).
}

Date of initial receipt: 31 January 1994

Date of acceptance: 15 September 1994

Ms 144SR-053 
Table 2. Geochemical results of carbonate analyses of platform carbonates, Hole 877A.

\begin{tabular}{|c|c|c|c|c|c|c|c|c|}
\hline $\begin{array}{l}\text { Core, section, } \\
\text { interval }(\mathrm{cm})\end{array}$ & Component & $\begin{array}{c}\mathrm{Mg} \\
(\mathrm{mg} / \mathrm{g})\end{array}$ & $\begin{array}{c}\mathrm{Sr} \\
(\mathrm{mg} / \mathrm{g})\end{array}$ & $\begin{array}{c}\mathrm{Fe} \\
(\mathrm{mg} / \mathrm{g})\end{array}$ & $\begin{array}{c}\mathrm{Mn} \\
(\mathrm{mg} / \mathrm{g})\end{array}$ & $\underset{(\mu \mathrm{g} / \mathrm{g})}{\mathrm{F}}$ & $\begin{array}{c}\delta^{13} \mathrm{C} \\
(\mathrm{PDB})\end{array}$ & $\begin{array}{c}\delta^{18} \mathrm{O} \\
\text { (PDB) }\end{array}$ \\
\hline $144-877 \mathrm{~A}-$ & & & & & & & & \\
\hline IR-I, $104-108$ & Matrix & 4.41 & 0.32 & 0.03 & 0.000 & 203 & 2.16 & -1.02 \\
\hline IR-I, $104-108$ & $\mathrm{RC}$ & 4.68 & 0.29 & 0.03 & 0.000 & 97 & 2.23 & -1.12 \\
\hline IR-I. 104-108 & Allochem & 4.76 & 0.52 & 0.03 & 0.000 & 107 & 2.42 & -0.14 \\
\hline IR-1, 34-36 & RC & 3.82 & 0.22 & 0.02 & 0.001 & 63 & 2.31 & -0.90 \\
\hline IR-1, 34-36 & Matrix & 4.13 & 0.29 & 0.03 & 0.000 & 248 & 2.14 & -1.58 \\
\hline IR-I, 99-101 & Micrite & 4.34 & 0.28 & 0.05 & 0.000 & 665 & 1.90 & -1.00 \\
\hline IR-1.99-101 & Matrix & 4.18 & 0.23 & 0.03 & 0.000 & 91 & 1.97 & -0.94 \\
\hline IR- $2,85-87$ & C. rudist & 4.29 & 0.91 & 0.11 & 0.001 & & 1.44 & -3.70 \\
\hline IR-2, 85-87 & A. rudist & 6.11 & 0.24 & 0.20 & 0.004 & 120 & 0.76 & -2.57 \\
\hline IR-2, 85-87 & $\mathrm{RC}$ & 5.56 & 0.30 & 0.34 & 0.003 & 86 & 1.26 & -2.17 \\
\hline IR-2, 85-87 & Matrix & 5.30 & 0.39 & 0.34 & 0.002 & 161 & 1.69 & -1.93 \\
\hline IR-2, 85-87 & C. rudist & 1.68 & 1.38 & 0.10 & 0.000 & 494 & 1.46 & -4.53 \\
\hline $2 \mathrm{R}-1,39-42$ & PLUC & 5.16 & 0.26 & 0.21 & 0.007 & 176 & 2.45 & -0.92 \\
\hline $2 R-1,39-42$ & Matrix & 4.57 & 0.30 & 0.05 & 0.000 & 167 & 2.01 & -0.41 \\
\hline $2 \mathrm{R}-1,39-42$ & PLUC & 5.19 & 0.23 & 0.05 & 0.006 & 91 & 2.54 & -0.99 \\
\hline $2 R-1,53-56$ & PLUC & 5.21 & 0.24 & 0.04 & 0.002 & 118 & 2.42 & -0.58 \\
\hline $2 \mathrm{R}-1,53-56$ & Matrix & 5.02 & 0.35 & 0.05 & 0.000 & 385 & 1.06 & -1.88 \\
\hline $3 R-1,2-4$ & $\mathrm{RC}$ & 3.44 & 0.26 & 0.03 & 0.004 & 129 & 2.24 & -0.12 \\
\hline $3 R-1,2-4$ & Matrix & 3.51 & 0.30 & 0.04 & 0.000 & 353 & 1.68 & -0.90 \\
\hline $3 \mathrm{R}-1.21-23$ & C. rudist & 0.85 & 1.45 & 0.01 & 0.000 & 104 & 2.07 & -4.16 \\
\hline $3 R-1,21-23$ & C. rudist & 2.13 & 0.86 & 0.03 & 0.000 & 524 & 1.63 & -2.55 \\
\hline $3 R-1,21-23$ & PLUC & 3.51 & 0.22 & 0.03 & 0.000 & 71 & & \\
\hline $3 \mathrm{R}-1,2 \mathrm{l}-23$ & Matrix & 3.22 & 0.25 & 0.03 & 0.001 & 179 & & \\
\hline $4 \mathrm{R}-1.135-137$ & Allochem & 6.55 & 0.38 & -0.03 & 0.000 & 87 & 2.10 & -1.36 \\
\hline $4 R-1,135-137$ & PLUC & 6.07 & 0.20 & 0.67 & 0.000 & 309 & 1.81 & -2.10 \\
\hline $4 \mathrm{R}-1,135-137$ & A. rudist & 1.26 & 1.30 & 0.21 & 0.005 & 103 & & \\
\hline $4 R-2,64-65$ & $\mathrm{RC}$ & 4.97 & 0.19 & 0.37 & 0.002 & 111 & & \\
\hline $4 R-2,64-65$ & C. rudist & 3.18 & 1.01 & 0.00 & 0.000 & & 1.76 & -3.68 \\
\hline $4 R-2,64-65$ & A. nudist & 5.38 & 0.45 & -0.02 & 0.000 & 280 & 1.64 & -2.49 \\
\hline $4 R-2,64-65$ & PLUC & 4.94 & 0.29 & 0.00 & 0.009 & 91 & 1.46 & -1.69 \\
\hline $4 R-2,64-65$ & A. rudist & 4.41 & 0.85 & 0.02 & 0.005 & 482 & & \\
\hline $4 R-3,17-22$ & Yellow CM & 5.65 & 0.24 & 0.51 & 0.005 & & 1.90 & -1.98 \\
\hline $4 \mathrm{R}-3,17-22$ & Red Igae & 5.38 & 0.32 & 1.28 & 0.004 & 159 & 1.17 & -2.30 \\
\hline $4 \mathrm{R}-3,17-22$ & $\mathrm{RC}$ & NA & $\mathrm{NA}$ & $\mathrm{NA}$ & NA & NA & 1.40 & -3.32 \\
\hline $5 R-1,69-73$ & A. rudist & 4.75 & 0.71 & 0.02 & 0.000 & 92 & 2.51 & -1.10 \\
\hline $5 R-1,69-73$ & $\mathrm{CC}$ & 4.60 & 0.38 & 0.03 & 0.002 & 175 & 2.33 & -1.20 \\
\hline $5 R-1,69-73$ & PLUC & 5.03 & 0.23 & 0.03 & 0.002 & 75 & 2.42 & -1.07 \\
\hline $5 R-2,11-14$ & Benthic forams. & 4.82 & 0.27 & 0.02 & 0.002 & 82 & 2.12 & -2.15 \\
\hline $5 \mathrm{R}-2,1 \mathrm{I}-14$ & PLUC & 4.64 & 0.26 & 0.03 & 0.001 & 67 & 2.09 & -2.03 \\
\hline $5 R-3,105-108$ & A. rudist & 0.92 & 2.08 & 0.10 & 0.000 & 78 & 2.92 & -1.97 \\
\hline $5 R-3,105-108$ & A. rudist & 6.22 & 1.29 & 0.26 & 0.000 & 99 & 2.25 & -2.16 \\
\hline $5 R-3,105-108$ & A. rudist & 4.62 & 1.34 & 0.11 & 0.002 & 84 & 2.07 & -1.94 \\
\hline $5 R-3,105-108$ & W. rudist & 0.88 & 2.51 & 0.11 & 0.000 & 54 & 3.06 & -2.65 \\
\hline $5 R-3,105-108$ & A. rudist & - & - & - & - & - & 2.39 & -1.44 \\
\hline $5 R-3,105-108$ & A. rudist & 0.55 & 2.35 & 0.01 & 0.000 & 85 & & \\
\hline 5R-3, $105-108$ & A. rudist & 4.76 & 0.93 & 0.13 & 0.000 & 81 & 2.87 & 0.17 \\
\hline $5 R-3,105-108$ & A. rudist & 4.11 & 1.37 & 0.04 & 0.003 & 87 & & \\
\hline $5 R-3,105-108$ & W. rudist & 0.79 & 2.82 & 0.05 & 0.000 & & & \\
\hline $5 R-3,105-108$ & W. rudist & 2.52 & 3.06 & 0.16 & 0.011 & 152 & 3.34 & -2.87 \\
\hline $5 R-3,105-108$ & $\mathrm{CC}$ & 12.85 & 1.09 & 0.29 & 0.014 & 354 & 2.88 & -2.32 \\
\hline $5 R-3,37-39$ & W. rudist & 0.36 & 2.48 & 0.00 & 0.004 & 86 & 2.40 & -2.51 \\
\hline $5 R-3,37-39$ & A. rudist & 4.15 & 1.06 & 0.01 & 0.004 & 63 & 3.11 & 1.25 \\
\hline $5 R-3,37-39$ & A. rudist & 0.22 & 2.18 & 0.14 & 0.005 & 48 & 2.53 & -2.80 \\
\hline $5 \mathrm{R}-3,37-39$ & $\mathrm{CC}$ & 13.52 & 1.21 & 0.23 & 0.004 & 457 & 2.95 & -2.19 \\
\hline $5 R-3,37-39$ & A. rudist & 4.31 & 2.21 & 0.37 & 0.002 & 285 & 2.55 & -2.33 \\
\hline $5 \mathrm{R}-3,41-44$ & A. rudist & 4.16 & 1.45 & 0.13 & 0.002 & 66 & 2.92 & -0.20 \\
\hline $5 R-3,41-44$ & A. rudist & 2.62 & 2.03 & 0.18 & 0.000 & 254 & 2.94 & -1.87 \\
\hline $5 \mathrm{R}-3,41-44$ & W. rudist & 0.31 & 2.87 & 0.26 & 0.000 & 64 & 3.18 & -2.83 \\
\hline $5 R-3,41-44$ & $\mathrm{CC}$ & 15.96 & 1.52 & 0.26 & 0.001 & 507 & 2.97 & -2.63 \\
\hline $5 R-3,41-45$ & A. rudist & 3.93 & 1.36 & 0.19 & 0.012 & & & \\
\hline $5 R-3,41-45$ & A. rudist & 3.51 & 1.61 & 0.18 & 0.008 & 170 & & \\
\hline $5 \mathrm{R}-3,4 \mathrm{I}-45$ & W. rudist & 0.42 & 3.05 & 0.25 & 0.007 & & & \\
\hline $5 R-3,41-45$ & $\mathrm{CC}$ & 13.40 & 1.10 & 0.24 & 0.000 & 404 & 2.44 & -2.39 \\
\hline $5 R-3,41-45$ & A. rudist & 1.90 & 1.95 & 0.28 & 0.000 & 91 & & \\
\hline $5 R-3,74-76$ & A. rudist & 6.62 & 0.66 & 0.21 & 0.002 & 111 & 3.05 & -0.16 \\
\hline $5 R-3,74-76$ & A. rudist & 2.63 & 2.11 & 0.22 & 0.000 & 148 & 2.91 & -2.51 \\
\hline $5 R-3,74-76$ & $\mathrm{CC}$ & 15.82 & 1.31 & 0.31 & 0.007 & 336 & 2.76 & -2.45 \\
\hline $5 R-3,74-76$ & PLUC & 4.77 & 0.35 & 0.09 & 0.003 & 113 & 3.13 & 1.11 \\
\hline 5R-3, 74-76 & C. rudist & 1.20 & 1.48 & 0.18 & 0.000 & 195 & 1.40 & -4.33 \\
\hline $5 R-3,74-76$ & A. cement & 5.83 & 0.84 & 0.00 & 0.000 & 83 & 2.98 & -1.56 \\
\hline SR-3, 74-76 & W. rudist & 0.67 & 2.17 & 0.52 & 0.000 & 74 & 2.81 & -2.57 \\
\hline $5 R-3,74-76$ & A. rudis! & 8.94 & 0.75 & 0.30 & 0.000 & 217 & 2.96 & -1.51 \\
\hline $5 R-3,74-76$ & A. rudist & 5.46 & 0.82 & 0.12 & 0.005 & 127 & & \\
\hline $5 R-3,76-78$ & A. rudist & 5.09 & 0.59 & 0.20 & 0.000 & 90 & 2.90 & 1.28 \\
\hline $5 R-3,76-78$ & W. rudist & 0.47 & 2.27 & 0.12 & 0.000 & 65 & 2.64 & -2.52 \\
\hline $5 R-3,76-78$ & A. rudist & 4.92 & 0.59 & 0.20 & 0.007 & 83 & & \\
\hline SR-3, 76-78 & W. rudist & 0.44 & 2.24 & 1.82 & 0.000 & 27 & 2.41 & -2.36 \\
\hline $5 R-3,76-78$ & A. rudist & 1.44 & 1.20 & 0.15 & 0.004 & 248 & & \\
\hline $5 R-3,76-78$ & $\mathrm{CC}$ & 15.96 & 0.68 & 0.24 & 0.008 & 366 & 3.37 & -2.55 \\
\hline $5 R-3,76-78$ & A. rudist & 3.92 & 1.74 & 0.08 & 0.004 & 107 & & \\
\hline $5 R-3,76-78$ & Coral & 3.65 & 7.91 & 0.46 & 0.004 & 891 & 4.46 & -3.02 \\
\hline 5R-3, 93-96 & W. rudist & 0.25 & 2.39 & -0.03 & 0.000 & 48 & 2.52 & -1.99 \\
\hline $5 R-3,93-96$ & W. rudist & 0.50 & 2.31 & 0.02 & 0.003 & 71 & 2.90 & -2.47 \\
\hline 5R-3, 93-96 & A. rudist & 2.46 & 2.08 & 0.05 & 0.000 & 69 & & \\
\hline SR-3, 93-96 & A. rudist & 4.79 & 1.88 & 0.07 & 0.002 & 85 & & \\
\hline $5 R-3,93-96$ & W. rudist & 0.52 & 3.06 & 0.00 & 0.000 & 84 & 3.87 & -2.52 \\
\hline $6 R-1,12-15$ & Matrix & 5.22 & 0.26 & 0.22 & 0.002 & 204 & 2.58 & -1.10 \\
\hline $6 \mathrm{R}-1,12-15$ & Matrix & 5.17 & 0.29 & -0.01 & 0.001 & 217 & 2.58 & -1.13 \\
\hline
\end{tabular}


Table 2 (continued).

\begin{tabular}{|c|c|c|c|c|c|c|c|c|}
\hline $\begin{array}{l}\text { Core, section, } \\
\text { interval }(\mathrm{cm})\end{array}$ & Component & $\underset{(\mathrm{mg} / \mathrm{g})}{\mathrm{Mg}}$ & $\begin{array}{c}\mathrm{Sr} \\
(\mathrm{mg} / \mathrm{g})\end{array}$ & $\underset{(\mathrm{mg} / \mathrm{g})}{\mathrm{Fe}}$ & $\underset{(\mathrm{mg} / \mathrm{g})}{\mathrm{Mn}}$ & $\begin{array}{c}\mathrm{F} \\
(\mu \mathrm{g} / \mathrm{g})\end{array}$ & $\begin{array}{l}\delta^{13} \mathrm{C} \\
(\mathrm{PDB})\end{array}$ & $\begin{array}{l}\delta^{18} \mathrm{O} \\
(\mathrm{PDB})\end{array}$ \\
\hline $6 \mathrm{R}-1,12-15$ & Allochem & 4.79 & 0.26 & 0.21 & 0.002 & 218 & 1.83 & -1.41 \\
\hline $6 \mathrm{R}-1,12-15$ & Matrix & 4.69 & 0.36 & 0.16 & 0.008 & 200 & 2.58 & -1.31 \\
\hline $6 \mathrm{R}-1,4-8$ & PLUC & 4.79 & 0.15 & 0.06 & 0.002 & 86 & 1.87 & -0.91 \\
\hline $6 \mathrm{R}-1,4-8$ & A. rudist & 5.18 & 0.50 & 0.03 & 0.000 & 407 & 1.62 & -2.25 \\
\hline $7 R-1.24-28$ & C. rudist & 1.94 & 1.24 & 0.03 & 0.000 & 479 & 0.72 & -4.01 \\
\hline $7 \mathrm{R}-1,38-41$ & C. rudist & 1.49 & 1.16 & 0.22 & 0.003 & 127 & 1.38 & -4.27 \\
\hline $7 R-1,38-41$ & A. rudist & 4.55 & 0.27 & 0.23 & 0.003 & 146 & 1.72 & -1.78 \\
\hline $7 \mathrm{R}-1,38-41$ & $\mathrm{RC}$ & 4.10 & 0.13 & 0.42 & 0.006 & 203 & 1.92 & -1.62 \\
\hline $7 R-1,38-41$ & C. rudist & 1.54 & 1.52 & 0.13 & 0.000 & 747 & 1.33 & -4.96 \\
\hline $7 R-1,38-41$ & Matrix & 4.63 & 0.39 & 0.39 & 0.002 & 161 & 1.68 & -1.81 \\
\hline $7 R-1,38-41$ & A. rudist & 4.40 & 0.54 & 0.31 & 0.010 & 304 & & \\
\hline $7 R-2,104-106$ & C. rudist & 3.29 & 0.74 & 0.02 & 0.001 & 554 & 1.29 & -2.43 \\
\hline 7R-2, $104-106$ & $\mathrm{RC}$ & 4.02 & 0.16 & 0.03 & 0.001 & 106 & 2.06 & -0.81 \\
\hline $8 \mathrm{R}-1,18-22$ & A. rudist & 5.13 & 0.23 & 0.01 & 0.001 & 81 & 1.70 & -1.72 \\
\hline $8 R-1.18-22$ & C. rudist & 4.42 & 0.89 & 0.00 & 0.000 & 694 & 1.65 & -2.98 \\
\hline $8 \mathrm{R}-1,18-22$ & C. rudist & 2.70 & 1.29 & 0.14 & 0.000 & 788 & 1.53 & -4.34 \\
\hline $8 \mathrm{R}-1,18-22$ & A. rudist & 4.17 & 0.62 & 0.16 & 0.000 & 414 & 1.03 & -2.97 \\
\hline $8 R-1,18-22$ & PLUC & 4.48 & 0.22 & 0.22 & 0.002 & 82 & 1.86 & -0.27 \\
\hline $8 \mathrm{R}-1,45-48$ & A. rudist & 6.58 & 0.38 & 0.18 & 0.002 & 109 & 1.04 & -2.08 \\
\hline $8 \mathrm{R}-\mathrm{I}, 45-48$ & RC & 5.36 & 0.16 & 0.29 & 0.003 & 117 & 1.22 & -1.26 \\
\hline $8 \mathrm{R}-\mathrm{I}, 45-48$ & Micrite & 5.24 & 0.41 & 0.18 & 0.009 & 308 & & \\
\hline $8 R-1,45-48$ & A. rudist & 5.96 & 0.53 & 0.18 & 0.007 & 91 & & \\
\hline $8 R-1,45-48$ & A. rudist & 5.75 & 0.53 & 0.08 & 0.007 & 103 & & \\
\hline $8 R-1,45-48$ & Algae & 5.29 & 0.33 & 0.07 & 0.005 & 244 & & \\
\hline $8 \mathrm{R}-\mathrm{I}, 45-48$ & PLUC & 5.18 & 0.24 & 0.14 & 0.003 & 118 & 1.23 & -1.43 \\
\hline $9 \mathrm{R}-1,21-25$ & Allochem & 5.22 & 0.24 & 0.33 & 0.001 & 246 & 0.77 & -1.67 \\
\hline $9 \mathrm{R}-1,21-25$ & Allochem & 4.70 & 0.19 & 0.05 & 0.002 & 274 & 1.16 & -1.02 \\
\hline $9 \mathrm{R}-1,21-25$ & A. coral & 6.12 & 0.38 & 0.14 & 0.004 & 188 & & \\
\hline $9 \mathrm{R}-1,2 \mathrm{l}-25$ & Allochem & 5.56 & 0.34 & 0.23 & 0.002 & 122 & 1.23 & -1.03 \\
\hline $9 \mathrm{R}-1,21-25$ & PLUC & 4.98 & 0.26 & 0.25 & 0.008 & 78 & 1.27 & -1.04 \\
\hline $9 \mathrm{R}-1,2 \mathrm{1}-25$ & A. coral & 5.66 & 0.31 & 0.21 & 0.003 & 143 & & \\
\hline $10 \mathrm{R}-1,3-10$ & PLUC & 5.55 & 0.14 & 0.02 & 0.002 & 0 & 1.33 & -0.84 \\
\hline $10 \mathrm{R}-1,3-10$ & A. coral & 5.48 & 0.22 & 0.12 & 0.002 & 107 & 1.57 & -1.06 \\
\hline $17 \mathrm{R}-1,11-15$ & Matrix & 3.97 & 0.83 & 0.35 & 0.007 & 120 & 1.50 & -1.33 \\
\hline $17 \mathrm{R}-1,11-15$ & Algae & 3.51 & 0.33 & 0.35 & 0.010 & 215 & & \\
\hline $17 \mathrm{R}-2,11-15$ & Benthic forams. & 3.82 & 0.27 & 0.69 & 0.025 & 203 & 1.13 & -1.38 \\
\hline $18 \mathrm{R}-1,47-48$ & Allochem & 4.80 & 0.24 & 0.63 & 0.016 & 134 & $\mathrm{NA}$ & NA \\
\hline 18R-1, 47-48 & Allochem & 4.67 & 0.20 & 0.79 & 0.020 & 129 & NA & NA \\
\hline $18 \mathrm{R}-1,47-48$ & Benthic forams. & 4.82 & 0.39 & 0.74 & 0.024 & 115 & 0.62 & -1.96 \\
\hline $18 R-1,47-48$ & Allochem & 4.57 & 0.22 & 0.03 & 0.014 & 136 & 0.81 & -1.14 \\
\hline $18 \mathrm{R}-1,47-48$ & Matrix & 4.74 & 0.26 & 0.05 & 0.013 & 182 & 0.66 & -1.31 \\
\hline $18 \mathrm{R}-1,77-78$ & Matrix & 4.50 & 0.32 & 0.11 & 0.007 & 231 & 1.86 & -0.92 \\
\hline $18 \mathrm{R}-1,77-78$ & Matrix & 4.49 & 0.36 & 0.50 & 0.010 & 232 & NA & NA \\
\hline $19 \mathrm{R}-1,27-30$ & Fe-matrix & 4.82 & 0.19 & 44.10 & 0.087 & 58 & 0.76 & -2.34 \\
\hline $19 \mathrm{R}-1,27-30$ & Matrix & 4.74 & 0.22 & 0.71 & 0.151 & 73 & 0.56 & -2.30 \\
\hline
\end{tabular}

Notes: $\mathrm{RC}=$ radaxial cement, $\mathrm{PLUC}=$ pyramidal-limpid-uniform extinction cement, $\mathrm{C}$, rudist $=$ calcite rudist, $\mathrm{A}$. rudist $=$ aragonite rudist, $\mathrm{CC}=$ columnar cement, and $\mathrm{W}$. rudist $=$ well-preserved aragonite rudist. $\mathrm{NA}=$ not analyzed, and dashes $=$ no data.

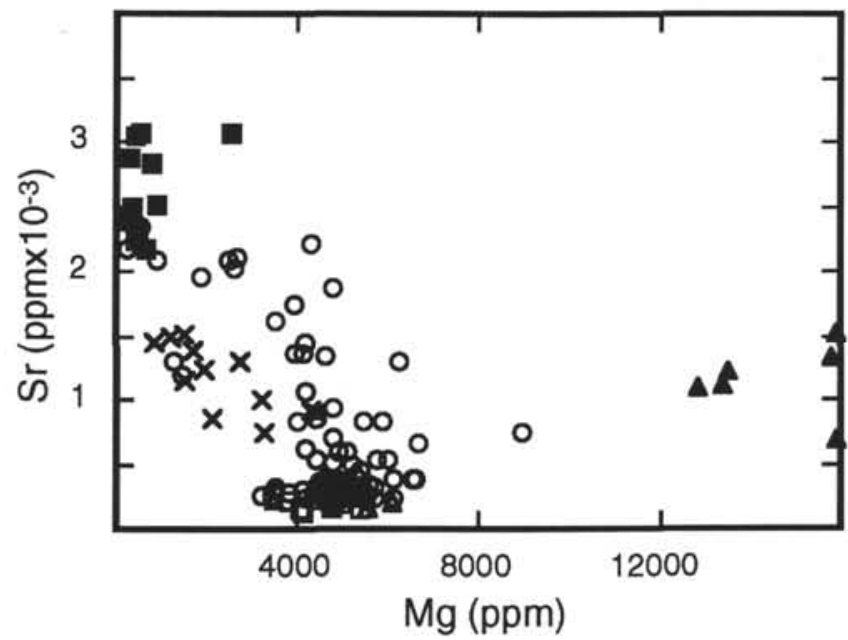

Figure 7. Mg vs. Sr. The unique chemistry of Mg-calcite, aragonite rudist, and coral are clearly defined. The slope of $\mathrm{Sr}$ incorporation vs. $\mathrm{Mg}$ content within the marine columnar cements is twice that of modern Mg-calcites, implying higher $\mathrm{Sr}$ contents in the Late Cretaceous ocean. Symbols are the same as in Figure 3. 

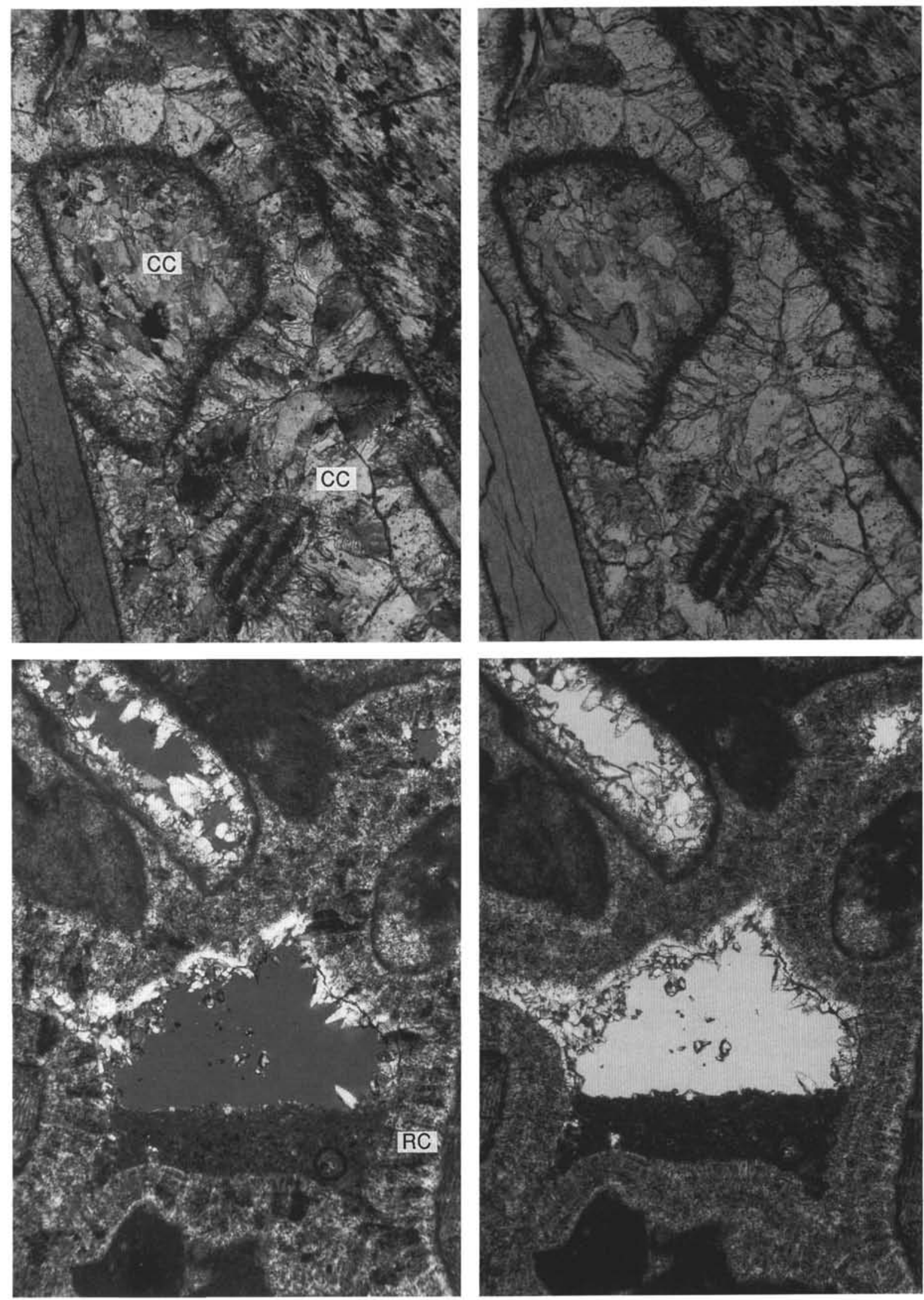

Plate 1. The top pair of photomicrographs shows CC in interparticle pore space and in a micrite envelope (Sample $144-877 \mathrm{~A}-5 \mathrm{R}-3,41 \mathrm{~cm})$. The bottom pair illustrates RC in interparticle pore space, showing several generations. Internal sediment and PLUC are evident in the large pore. Note that the micrite envelope only has PLUC (Sample 144-877A-1R-1, $137 \mathrm{~cm}$ ). Photomicrographs on the right are taken in plain light; on the left, crossed polars. 